\title{
SOSIAALITYÖNTEKIJÖIDEN TYÖN KUORMITTAVUUS JA SIINÄ TAPAHTUNEET MUUTOKSET VUOSINA 2000-2012
}

Sanna-Riitta Junnonen: YTM, tobtorikoulutettava, Itä-Suomen yliopisto, Juha Hämäläinen: YTT, KL,
professori, Itä-Suomen yliopisto, Pertti Töttö: YTT, professori (emeritus), Itä-Suomen yliopisto,
Raija Väisänen: YTT, yliopistonlebtori (emerita), Itä-Suomen yliopisto, Otso Rantonen: YTM, tohtori-
koulutettava, vieraileva tutkija, Turun yliopisto, Paula Salo: PsT, professori, Turun yliopisto ja Työterveyslaitos

sanrita@live.com;juba.hamalainen@uef.fi;pertti.totto@uef.fi;

raija.vaisanen@uef.fi; optran@utu.fi;paula.salo@ttt.fi

Janus vol. 27 (2) 2019, $x x x-x x x$

Tiivistelmä

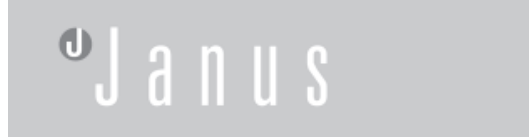

A.

Artikkelissa tarkastellaan, mitä kuormittavia tekijöitä sosiaalityössä esiintyy ja millaisia muutoksia niissä on tapahtunut 2000-luvun Suomessa. Artikkelin pohjana oleva tutkimus kohdentui sosiaalityöntekijöihin.Vertailuryhminä olivat erityisopettajat, psykologit ja lastentarhanopettajat. Aineistona käytettiin Työterveyslaitoksen Kunta10-tutkimusaineistoa, jota Työterveyslaitos on kerännyt vuodesta 1997 lähtien. Analyysimenetelminä käytettiin lineaarista regressiota poikkileikkausaineistoon ja lineaarista latenttia kasvukäyrämallia toistomittaus- ja seka-aineistoon. Artikkelissa keskityttiin työn hallintaan, työn palkitsevuuteen ja työn paineisiin. Ammattiryhmien välillä havaittiin eroja: sosiaalityöntekijät kokivat enemmän kuormitusta työssään kuin psykologit, erityisopettajat tai lastentarhanopettajat. Työhön liittyvissä psykososiaalisissa tekijöissä ei havaittu olennaista muutosta vuosina 2000-2012 missään tutkituista ammattiryhmistä.Vaikuttaa siltä, että työn luonne tutkituissa ryhmissä on pysynyt samankaltaisena.

\section{JOHDANTO}

Suomalaisia sosiaalityöntekijöitä kuormittavat erityisesti kiireinen työtahti, suuret asiakasmäärät, työyhteisön ongelmat ja rooliristiriidat työssä (Saarinen ym. 2012, 413-415). Erityisinä kuormitustekijöinä on mainittu myös työn jakaantuminen moniin tehtäviin, jatkuvat keskeytykset työssä sekä yleinen kiireisyys (Niemelä \& Hämäläinen 2001, 92-93). On todettu, että työyhteisöjen ristiriidat ja ongelmat työpaikalla lisäävät kuormittavuuden tunnetta (Hämäläinen \& Niemelä 2006, 23-24). Työtä haittaavat riittämättömät resurssit ja sitä tehdään paljon itsenäisesti ilman työparia. Vajavaisilla resursseilla pystytään yleensä tarjoamaan lakisää- teiset palvelut, mutta palvelujen kehittäminen ja suunnitteleminen jää usein vähemmälle (Salo ym. 2016, 6). Kuormitustekijöitä sosiaalityössä ovat myös asiakasvastuu, monimutkainen ongelmanratkaisu ja asiakkaiden tunteiden vastaanottaminen ja käsitteleminen (Laine ym. 2010). Lisähaastetta tuo niin Suomessa kuin muualla Euroopassa suurten ikäluokkien eläköityminen ja eliniän pidentyminen (Oksanen 2012, 11). Työstä häviää osaamista ja myös hoivan sekä sosiaalityön tarve kasvaa väestön ikääntymisen myötä. Riskinä on, että alentuneet valmiudet harjoittaa eettisesti vastuullista sosiaalityötä ovat yhteydessä työhyvinvoinnin heikkenemiseen (Mänttäri-van der Kuip 2015a). 
Artikkelissa käytetään Työterveyslaitoksen Kunta10-tutkimusaineistoa, jota on kerätty vuodesta 1997 lähtien. Kunta10-tutkimuksessa tutkitaan kunta-alan työtä, työssä tapahtuvia muutoksia sekä työelämän vaikutuksia henkilöstön terveyteen ja hyvinvointiin kymmenessä tutkimuskunnassa. Kunnat ovat Espoo, Naantali, Nokia, Oulu, Raisio, Tampere, Turku, Valkeakoski, Vantaa ja Virrat. Tähän tutkimukseen on valittu vuodet 2000, 2004, 2006, 2008, 2010 ja 2012, jolloin on kerätty aineistoa Kunta10-tutkimuksessa. Kunta10-tutkimusaineisto pitää sisällään kaikki ammattiryhmät. Tämä artikkeli on osa laajempaa tutkimusta, jossa on tarkasteltu monipuolisesti sosiaalityöntekijöiden työn kuormittavuutta. Artikkelissa tarkastellaan sosiaalityöntekijöiden työn kuormittavuutta verrattuna eräisiin muihin kunnallisiin ammattiryhmiin, joiden työ on osin koulutuksen ja alan naisvaltaisuuden suhteen verrattavissa sosiaalityöhön. Näissä ammateissa tehdään ihmisläheistä vuorovaikutustyötä. Ammatit, joihin sosiaalityöntekijöitä verrataan, ovat lastentarhanopettajat, erityisopettajat ja psykologit. Vertailusuhde mahdollistaa tarkastelun muihin ammattiryhmiin. Sosiaalityöntekijät erottuivat sairaspoissaolojen määrän ja työn kuormittavuuden kokemisessa Kunta10-aineistossa. Aineisto koostuu kaiken kaikkiaan 7614 työntekijästä. Artikkelissa vastataan kysymyksiin (1) millainen on sosiaalityöntekijöiden työn kuormittavuus verrattuna lastentarhanopettajiin, erityisopettajiin ja psykologeihin ja (2) miten työn kuormittavuus on muuttunut vuosina 2000-2012. Tavoitteena on tarkastella sosiaalityöntekijöiden työn kuormittavuutta pitkittäisnäkökulmasta. Pitkittäistutkimusta sosiaalityönte- kijöiden työhyvinvoinnista on tehty hyvin vähän ja siitä ei ole ollut selvää kuvaa (esim. Tham 2007; Rantonen ym. 2017).

\section{TYÖPAINEET, TYÖN HALLINTA JA TYÖN PALKITSEVUUS SOSIAALITYÖSSÄ}

Työn vaativuutta pidetään sosiaalialalla yleisesti kuormittavana tekijänä. Työn vaativuuteen liittyy läheisesti yhteiskunnan muutoksista johtuva sosiaalialan työn tietotaidon ja erilaisten valmiuksien ylläpito sekä oikeudellisten asioiden hallinta. Sosiaalialan työ koetaan hyvin vastuulliseksi. Vastuu tuo toisaalta työhön mielekkyyttä ja palkitsee työntekijää, mutta toisaalta voi kuormittaa liikaa. Yhteistyön lisääminen työntekijöiden kesken helpottaisi vastuuta ja vastuujaon ongelmia. (Hämäläinen \& Niemelä 2006, 24.) Havainto sosiaalityöntekijöiden vähäisistä vaikutusmahdollisuuksista oman työn järjestämiseen on tärkeä. Vaikutusmahdollisuuksien puutteen ja työn stressaavuuden välinen yhteys on todettu lukuisissa työpsykologisissa tutkimuksissa (Raunio 2003, 57). Työntekijöille on tärkeää, että he voivat jakaa tavoitteet ja arvot työnantajan kanssa, mikä on tärkeä osa sitoutumista (normatiivinen sitoutuminen) (Huxley ym. 2005, 1077).

Sosiaalialalla työn mielenkiintoa ja vaihtelevuutta lisää se, että työssä on mahdollisuus olla muiden ihmisten kanssa vuorovaikutuksessa ja auttaa heitä. Sosiaalialalla työn kuormittavuus näyttäisi olevan yhteydessä työntekijän koulutukseen. Mitä korkeampi koulutus on, sitä suurempana työn kuormittavuus koetaan, koska myös vastuu työstä kasvaa. (Hämäläinen \& Niemelä 2006,24.) 
Suomalaista sosiaalityön kenttää leimaa krooninen työntekijäpula (erityisesti kunnallisessa sosiaalityössä), jota on yritetty paikata palkkaamalla sijaisia, joilla ei ole kelpoisuutta. Tilanne on ongelmallinen sekä kelpoisille työntekijöille että vailla kelpoisuutta oleville sijaisille, koska työyhteisössä epävarmuus lisääntyy ja työn jatkuvuus vähenee. (Saarinen ym. 2012, 413.)

Sosiaalityötä voidaan luonnehtia toiminnaksi, jonka muotoutumiseen vaikuttavat samanaikaisesti yhteiskunnassa vallitseva poliittisideologinen keskustelu, sosiaalityön organisatorisprofessionaalinen toiminta sekä sosiaalityöntekijän ja asiakkaan välinen suhde (Payne 2005, 17-18). Jatkuvan vuorovaikutuksen kautta kaikki areenat vaikuttavat toisiinsa. Muutokset yhteiskunnallisessa tilanteessa ja niiden vaikutus asiakkaiden elämäntilanteisiin voivat vaikuttaa sosiaalityön toiminnan muotoutumiseen palvelun kysynnän kautta. Tämä taas voi aiheuttaa muutoksia työn järjestämiseen ja ammatillisiin käytäntöihin. (Kankainen 2012, 10.) Sosiaalityön kansainvälinen määritelmä (IFWS 2000) asettaa sosiaalityön päämääräksi kansalaisten hyvinvoinnin lisäämisen. Näin sosiaalityön instituutio määritellään hyvinvointipalveluiden ja hyvinvointietiikan ammatilliseksi instrumentiksi (Niemelä 2011, 13). Suomalaiselle sosiaalityölle tunnusomainen järjestelmäkeskeisyys näkyy virastokeskeisenä toimintatapana myös kehittämistoiminnassa. Tämä kahlitsee helposti luovaa ja kokeilevaa ajattelua, kun sosiaalityön tiedontuotanto kiinnittyy sen käytännölliseen tehtävään modernin yhteiskunnan ammatillisena toimialana (Hämäläinen 2014, 64 ja 75). Hyvinvointivaltioon paikantuvana toimintana sosiaalityötä määrittää olennaisesti viimesijaisuus. Sosiaalityö on osa ammatillista toimintaa, joka viime kädessä vastaa ihmisen selviytymisestä, toimeentulosta ja toimintakyvystä yhteiskunnassa.

Asiakkaiden palvelutarpeissa ja toimintaympäristössä tapahtuneet muutokset, henkilöstön osaamisen vajeet sekä pula pätevistä sosiaalityöntekijöistä ja ammatin vetovoiman säilyttäminen palvelurakenteiden uudistuessa edellyttävät erityisesti sosiaalityön osaamisen vahvistamista ja työn uudelleen organisointia lähivuosina (Karjalainen \& Sarvimäki 2005, 3). Työhyvinvoinnin puutteet ovat kasvava huolenaihe sosiaalialan ammateissa. Sosiaalityöntekijöillä on kohonnut riski kokea työolosuhteisiin liittyvää psykologista ahdistusta työtehtävien luonteen vuoksi (Baldschun ym. 2016, 524) ja heidän työkyvyttömyytensä johtuu mielenterveyden ongelmista useammin kuin muilla ammattiryhmillä (Rantonen ym. 2017).

\section{SOSIAALITYÖNTEKIJÖIDEN TYÖHYVINVOINTI}

Sosiaalialalla työn mielekkyyden on koettu viime vuosina kehittyneen yleisesti huonompaan suuntaan ja henkilöstön vaikutusmahdollisuuksien vähentyneen paitsi Suomessa myös muissa Pohjoismaissa (Laine ym. 2011; Tham 2007). Suomessa ja Ruotsissa sairauspoissaolot johtuvat sosiaalityöntekijöillä mielenterveyden ongelmista useammin kuin muilla ammattiryhmillä (Rantonen ym. 2017). Yksi sosiaalialan ja erityisesti sosiaalityön ongelma Pohjoismaissa on, että työntekijät vaih- 
tavat aktiivisesti työpaikkoja ja hakeutuvat pois asiakastyöstä (esim. Tham 2007). Tämä myös lisää entisestään töihin jäävien työmäärää. Sosiaalityön konteksti Pohjoismaissa on samantyyppinen sekä normatiivisten tavoitteiden ja lainsäädännön että institutionaalisten ratkaisujen osalta (Saarinen ym. 2012, 403-404).

Saarinen ym. ovat koonneet hyvin kansainvälistä tutkimusta sosiaalityön kuormittavuudesta (esim. Balloch ym.1998; Coffrey ym. 2004; Lloyd 2005). Tutkimuksen mukaan myötätuntouupuminen on vaarana sosiaalityön ammatissa (Adams ym. 2006). Tulokset maiden välisestä vertailusta ovat selviä. Suomalaiset sosiaalityöntekijät ovat erittäin kuormittuneita ja kokevat paljon ristiriitoja työssään. Ero muihin Pohjoismaihin on merkittävä. Kansainvälistä tutkimusta voidaan kuitenkin hyödyntää rajallisesti, koska tutkittavat asiat ovat kontekstisidonnaisia ja mahdollisesti vaihtelevat eri yhteiskunnissa (Shardlow \& Hämäläinen 2015; Hämäläinen \& Shardlow 2016). Kansainvälisissä tutkimuksissa voidaan kuitenkin havaita samankaltaista kuormittuneisuutta ja hallintokeskeisyyttä kuin kotimaisissa (McFadden 2015, Ravalier 2017). Suomen erityistilanteelle voi lähteä etsimään selityksiä useasta tekijästä. Politiikan muutokset, köyhyyden lisääntyminen ja sen pitkittyminen voivat olla omiaan lisäämään suomalaisten sosiaalityöntekijöiden työn kuormittavuutta ja ristiriitoja työssä (Saarinen ym. 2012, 413).

Sosiaalialan henkilöstön työn muuttuneista kohteista ja ehdoista sekä niiden asettamista vaatimuksista työn sisällölle ja organisoinnille tehtiin tutkimuksia 1990-luvulla (esim. Arnkil 1991; Rauhala 1991; Lindqvist \& Rajavaara 1994). Myös työyhteisökysymyksiä on tutkittu jonkin verran aikaisemmin (esim. Elovainio \& Lindström 1993). Tanja Viinamäki (1997) on tutkinut opettajien ja sosiaalityöntekijöiden stressiä ja psyykkistä hyvinvointia. Perusväestöön verrattuna opettajilla ja sosiaalityöntekijöillä ilmeni mielenterveyden häiriö lähes kaksi kertaa useammin (Viinamäki 1997). Tanninen ja Julkunen (1993, 170-171) ovat määritelleet ja 1990-luvulla, että sosiaalityöhön on todettu liittyvän ristiriitaisia paineita ja kuormittuneisuutta. Ylirasittuneisuus on näyttänyt olleen varsin yleistä sosiaalialalla. Kehittämistoimilla voidaan kuitenkin tuottaa työntekijöiden terveyden- ja vireydentilassa myönteistä kehitystä. (Niemelä \& Hämäläinen 2001, 91.)

Vuonna 2016 julkaistuissa tutkimuksessa todettiin, että sosiaalityöntekijöillä on jopa kaksinkertainen riski päätyä työkyvyttömäksi mielenterveyden ongelmien vuoksi verrattuna muihin kunta-alalla työskenteleviin. Kyseisessä tutkimuksessa sosiaalityöntekijöitä verrattiin lastentarhanopettajiin, erityisopettajiin ja psykologeihin (Rantonen ym. 2017.) Vastavia havaintoja oli tehty aikaisemmissa tutkimuksissa (esim. Hämäläinen \& Niemelä 2006; Meltti \& Kara 2009; Laine 2011). Kunta-alan tai sosiaali- ja terveydenhuollon henkilöstöä käsittelevissä tutkimuksissa sosiaalityöntekijät ovat olleet mukana yhtenä työntekijäryhmänä useiden muiden kanssa, mutta näissä tutkimuksissa ongelmana on ollut, että sosiaalityöntekijöitä on ollut mukana määrällisesti kovin vähän (esim. Laine ym. 2011). 2000-luvun alussa sosiaa- 
lialan työntekijät kokivat työtahtinsa jatkuvasti kiristyneen, työmäärän lisääntyneen ja työn muuttuneen yhä vaativammaksi (Hämäläinen \& Niemelä 2006, 91). Suomalaisten sosiaalityöntekijöiden työhyvinvointi vaikuttaa hälyttävän huonolta, mikä vaikuttanee asiakastyön laatuun (Saarinen ym. 2012, 415). Työhyvinvoinnin ongelmien on nähty olevan yhteydessä toimintamahdollisuuksien rajoittuneisuuteen niukkuuden aikakaudella (Mänttäri-van der Kuip 2015b). Työhyvinvoinnin tila on heikko erityisesti lastensuojelun sosiaalityössä (Baldshun ym. 2016). Vertailevaa tutkimusta sosiaalityöntekijöiden ja muiden ammattiryhmien välillä on tehty kuitenkin verraten vähän.

Kunta10-tutkimus pitää sisällään kunta-alan kaikki ammattiryhmät. Sosiaalityötekijät erottuivat siinä muista sairauspoissaolojen ja kuormittuneisuuden osalta. Yhteiskunnallinen, ajallinen muutos vaikuttaa eri ammattiryhmissä eri tavoin (Rantonen ym. 2017), joten ajalliseen muutokseen on kiinnitettävä huomiota. Tässä tutkimuksessa työn kuormittavuuden mittareina käytetään vakiintuneita, validiteetiltaan ja reliabiliteetiltaan hyviksi havaittuja työhön liittyviä psykososiaalisia tekijöitä mittaavia kysymyssarjoja. Artikkelissa keskitytään kolmeen ulottuvuuteen: työpaineisiin, työn hallintaan ja sen palkitsevuuteen. Koska työn kuormittavuus oletettavasti vaihtelee työntekijän iän ja sukupuolen mukaan, tarkastellaan ammattiryhmien (sosiaalityöntekijät, lastentarhanopettajat, erityisopettajat ja psykologit) työn kuormittavuutta ikä- ja sukupuolivakioituna suureena. Kyseessä on pitkittäistutkimus, jollaisia on tästä aiheesta tehty verrattain vähän.

\section{Aineisto, muUttujat JA ANALYYSIMENETELMÄT}

\section{Asetelma ja osallistujat}

Tutkimuksen aineistona käytettiin Työterveyslaitoksen keräämää Kunta10kyselyn osa-aineistoa. Siinä on kerätty tietoa kunta-alan työstä ja työssä tapahtuvista muutoksista sekä tutkittu työhön liittyvien psykososiaalisten tekijöiden vaikutuksia työntekijöiden terveyteen ja hyvinvointiin. Kymmenessä kunnassa (Espoo, Naantali, Nokia, Oulu, Raisio, Tampere, Turku, Valkeakoski, Vantaa ja Virrat) vuodesta 1997 alkaen kahden vuoden välein toistetusta kyselystä analysoitiin vuosien 2000, 2004, 2006, 2008, 2010 ja 2012 aineistoa siten, että mukana olivat sosiaalityöntekijät, lastentarhanopettajat, erityisopettajat ja psykologit. Sosiaalityöntekijöitä verrattiin näihin kolmeen akateemisesti koulutettuun naisvaltaiseen ammattiryhmään, jotka kaikki työskentelevät samankaltaisessa ihmisläheisessä työssä. Kyse on naisvaltaisista aloista, joiden palkkaustaso on myös lähellä toisiaan. Kyselyiden vastausprosentit olivat (aikajärjestyksessä) 67, 65, 69, 70, 69 ja 69. Taulukossa 1 on esitetty analyysiin mukaan otettujen ammattiryhmien koko kunkin mittauskerran aineistossa. 
Taulukko 1. Eri ammattiryhmiin kuuluvien vastaajien lukumäärä kussakin Kunta10-aineistossa.

\begin{tabular}{lllllll}
\hline $\begin{array}{l}\text { Ammattiryhmä } \\
\text { Vuosi }\end{array}$ & 2000 & 2004 & 2006 & 2008 & 2010 & 2012 \\
\hline SOSIAALITYÖNTEKIJ̈̈ & 441 & 502 & 551 & 642 & 661 & 730 \\
LASTENTARHANOPETTAJA & 1478 & 1375 & 1574 & 1792 & 1891 & 2099 \\
ERITYISOPETTAJA & 391 & 459 & 529 & 742 & 746 & 803 \\
PSYKOLOGI & 186 & 177 & 215 & 288 & 322 & 357 \\
\hline Yhteensä & 2496 & 2513 & 2869 & 3464 & 3620 & 3989 \\
\hline
\end{tabular}

Aineisto on keruutapansa vuoksi menetelmällisesti haastava. Ensinnäkin sen havaintoyksiköt ovat alueellisesti ryvästyneitä, koska saman kunnan havainnot eivät lähtökohtaisesti ole toisistaan riippumattomia. Tällaisessa aineistossa perinteiset tilastolliset menetelmät tuottavat keskiarvoille ja muille tunnusluvuille liian tarkkoja estimaatteja. Niiden keskivirheet ovat deflatoituneita, toisin sanoen ryvästyneillä aineistoilla saadaan liian usein tilastollisesti merkitseviä tuloksia. Koska kuntien välinen vaihtelu työhyvinvoinnin indikaattoreissa oli kuitenkin hyvin vähäistä niiden sisäiseen vaihteluun verrattuna (sisäkorrelaatiolla mitaten $0,5-1,2$ prosenttia kokonaisvarianssista), aineistoa analysoitiin ikään kuin se ei olisi ryvästynyt.

Toinen aineiston erikoispiirre on, ettei se ole eri ajankohdista kerätty puhdas poikkileikkausaineisto, jossa vastaajat olisi kullakin kerralla valittu satunnaisesti, eikä liioin puhdas toistomittausaineisto, jossa vastaajat olisivat joka mittauskerralla samoja. Aineistossa on mukana (1) pieni joukko vastaajia, jotka olivat mukana kyselyssä kaikkina kuutena mittauskertana (toistomittaus- aineisto, $N=489$ ), (2) vastaajia, jotka olivat mukana vähintään kahdella, mutta eivät kuudella mittauskerralla (sekaaineisto, $N=4115$ ), sekä (3) sellaisia jotka olivat vastanneet kyselyyn vain yhtenä mittausajankohtana (poikkileikkausaineistot, $\mathrm{N}=624+286+304$ $+392+381+1023=3010)$. Kaikkiaan analyysissa oli siis mukana 7614 eri henkilöä (ja heistä yhteensä 18951 mittausta).

\section{Mittareiden rakentaminen}

Työn kuormittavuutta mitattiin kolmella yhdistetyllä mittarilla, jotka olivat aineistossa valmiina yhdistettyinä. Näin ollen mittareiden psykometristen ominaisuuksien tarkasteleminen (Cronbachin alfan laskeminen ja sen oletusten - yksiulotteisuuden ja tosiarvoekvivalenssin - testaaminen) ei ollut mahdollista. Mittarit ovat kuitenkin aikaisemmassa tutkimuksessa hyväksi havaittuja (Karasek \&Theorell 1990). Ne on muodostettu seuraavasti.

Työn hallintaa selvitettiin kysymyssarjalla, jossa vastaajalta tiedusteltiin osallistumis- ja vaikutusmahdollisuuksia työssä seuraavilla väittämillä: 
- Voin tehdä paljon itsenäisiä päätöksiä työssäni

- Työni edellyttää minulta luovuutta

- Työni vaatii, että opin uusia asioita

- Työhöni kuuluu paljon samanlaisina toistuvia tehtäviä

- Minulla on paljon omiin töihini liittyvää sananvaltaa

- Työni vaatii pitkälle kehittyneitä taitoja

- Työssäni saan tehdä paljon erilaisia asioita

- Minulla on mahdollisuus kehittää minulle ominaisia erityiskykyjäni

- Minulla on hyvin vähän vapautta päättää, miten teen työni.

Vastausvaihtoehdot olivat 1 = täysin samaa mieltä, 2 = jokseenkin samaa mieltä, $3=$ en samaa enkä eri mieltä, $4=$ jokseenkin eri mieltä, $5=$ täysin eri mieltä. Kahta lukuun ottamatta osioiden asteikko käännettiin ja niiden keskiarvoa [MEAN(v1_6, .., v1_14)] käytettiin yhdistettynä mittarina.

Työn palkitsevuutta mittaava asteikko muodostettiin kysymyssarjasta, jossa vastaajalta tiedusteltiin omaa työtä ja sen kuormittavuutta seuraavilla väittämillä:

- Saan ansaitsemani arvostuksen esimiehiltäni

- Etenemismahdollisuuteni ovat heikot

- Olen kokenut tai uskon kokevani epämieluisan muutoksen työssäni

- Työssäni on paljon epävarmuustekijöitä

- Saan töissä ansaitsemani arvostuksen ja kunnioituksen, kun ottaa huomioon kaikki ponnisteluni ja saavutukseni
- Etenemismahdollisuuteni työelämässä ovat riittävän hyvät, kun ottaa huomioon kaikki ponnisteluni ja saavutukseni

- Palkkani/tuloni ovat riittävät, kun ottaa huomioon kaikki ponnisteluni ja saavutukseni.

Vastausvaihtoehdot olivat 1 = täysin samaa mieltä, 2 = osittain samaa mieltä, $3=$ osittain eri mieltä, $4=$ täysin eri mieltä. Neljä asteikkoa käännettiin ja osioista muodostettiin yhdistetty mittari $\left[\operatorname{MEAN}\left(v 3 \_4, \ldots, v 3 \_10\right)\right]$.

Työpaineita kuvaava mittari tehtiin kysymyksistä, joissa vastaajalta tiedusteltiin työn vaativuutta, määrää ja työpaineita seuraavilla väittämillä:

- Minun on oltava nopea työssäni

- Työni vaatii erittäin kovaa työntekoa

- Minulta edellytetään kohtuutonta työmäärää

- Minulla on tarpeeksi aikaa saada työni tehdyksi

- Työni on erittäin kiivastahtista

Vastausvaihtoehdot ovat 1 = täysin samaa mieltä, 2 = melko samaa mieltä, 3 $=$ en samaa enkä eri mieltä, $4=$ melko eri mieltä, 5 = täysin eri mieltä. Yhtä lukuun ottamatta asteikot käännettiin ja niiden keskiarvoa [MEAN(v1_1, ..., v1_5)] käytettiin yhdistettynä mittarina.

Kunta10-tutkimuksessa käytetään Karasekin ja Sigegristin mittareita kahtena eri näkökulmana työn kuormittavuuteen. Niitä käytetään esim. vertaamaan arvoa tietyssä ryhmässä suhteessa tasoon koko aineistossa. Karasekin mallissa liitetään yhteen työpaineet ja työn hallin- 
ta ja Siegristissä ponnistelut ja palkkiot. Tässä artikkelissa ei kuitenkaan käytetty Siegristin ponnistelut-väittämiä. Karasekin mallissa liitetään yhteen työpaineet ja työn hallinta. Mittarit ovat hyvin vakiintuneet. Tekijänoikeudet kuitenkin kieltävät kysymysten julkaisemisen yksittäisinä tai kysymyssarjojen julkaisemisen kokonaisuudessaan. Ryhmään "työpaineita paljon ja työn hallintaa vähän" luokiteltiin henkilöt, jotka ilmoittivat työpaineita esiintyvän enemmän ja työn hallintaa vähemmän kuin Kunta10-aineistossa keskimäärin. Tulos esitetään em. ryhmään kuuluvien prosenttiosuutena. Mitä suurempi arvo, sitä useammalla esiintyy epäsuhtaa työpaineiden ja työn hallinnan välillä. Ryhmään "työhön panostusta paljon ja palkitsevuutta vähän" luokiteltiin henkilöt, jotka ilmoittivat työhön panostusta esiintyvän enemmän ja työn palkitsevuutta keskimäärin vähemmän kuin Kunta10-aineistossa. Tulos esitetään em. ryhmään kuuluvien prosenttiosuutena. Mitä suurempi arvo, sitä useammalla esiintyy epäsuhtaa työhön panostamisen ja työn palkitsevuuden välillä. (Karasek \&Theorell 1990, Siegrist ym 2009.)

Ammattiryhmä-muuttuja tehtiin siten, että arvo 1 tarkoittaa sosiaalityöntekijää ja 0 muita ammattiryhmiä. Emme siis ole kiinnostuneita lastentarhanopettajien, erityisopettajien ja psykologien keskinäisistä eroista vaan ainoastaan sosiaalityöntekijöiden ja muiden välisistä eroista. Näiden kahden ryhmän väliset erot voivat periaatteessa johtua joidenkin kolmansien tekijöiden vaikutuksesta, jos esimerkiksi ammattiryhmien ikäjakaumat eroavat toisistaan tai jos alalle on valikoitunut eri määriä naisia ja miehiä. Muitakin sekoittavia tekijöitä, joilla voi olla vaikutusta työhyvinvointiin, voidaan olettaa olevan, mutta valitettavasti käytetty aineisto on tässä suhteessa kovin niukka. Lopulta ikä ja sukupuoli jäivät ainoiksi käyttökelpoisiksi kontrollimuuttujiksi. Ikä keskistettiin (kunkin vastaajan iästä vähennettiin kaikkien vastaajien keskiikä), mikä helpottaa regressiomallien tulkintaa, koska keskistetyn muuttujan keskiarvo on 0.Tällöin mallin leikkauspiste tarkoittaa keski-ikäisen vastaajan keskiarvoa selitettävällä muuttujalla. Iän mahdollinen epälineaarinen yhteys kontrolloitiin lisäämällä malleihin toisen asteen termi (ikä^ikä). Jos sen merkitsevä kerroin on positiivinen tai negatiivinen, tämä tarkoittaa, että keski-ikäisillä on muita alhaisempi tai korkeampi keskiarvo selitettävällä muuttujalla. (Ketokivi 2015, 137-142).

\section{Analyysimenetelmät}

Aineisto sisältää siis sekä poikkileikkausmittauksia että täydellisiä ja epätäydellisiä toistomittauksia. Tarkastellaan ensin poikkileikkausaineistoja. Joka ajankohdasta voidaan kullekin ammattiryhmälle laskea kolmen kuormittavuusmittarin keskiarvo ja verrata sitä ajankohtien ja ammattiryhmien välillä. Ikä- ja sukupuolivakioidut keskiarvot saadaan kullekin ajankohdalle estimoitujen lineaaristen regressiomallien leikkauspisteiden avulla. Näin saadaan näkyviin sosiaalityöntekijöiden ja muiden tasoerot sekä niiden vaihtelu ajankohdasta toiseen. Varsinainen muutos jää tällä tavoin kuitenkin katveeseen. Jos esimerkiksi sosiaalityöntekijöiden työn hallinta on poikkileikkausaineistoissa kasvanut kahdentoista vuoden aikana, johtuu kasvu siitä, että ammattiryhmän koostumus on muuttunut eli vastaajis- 


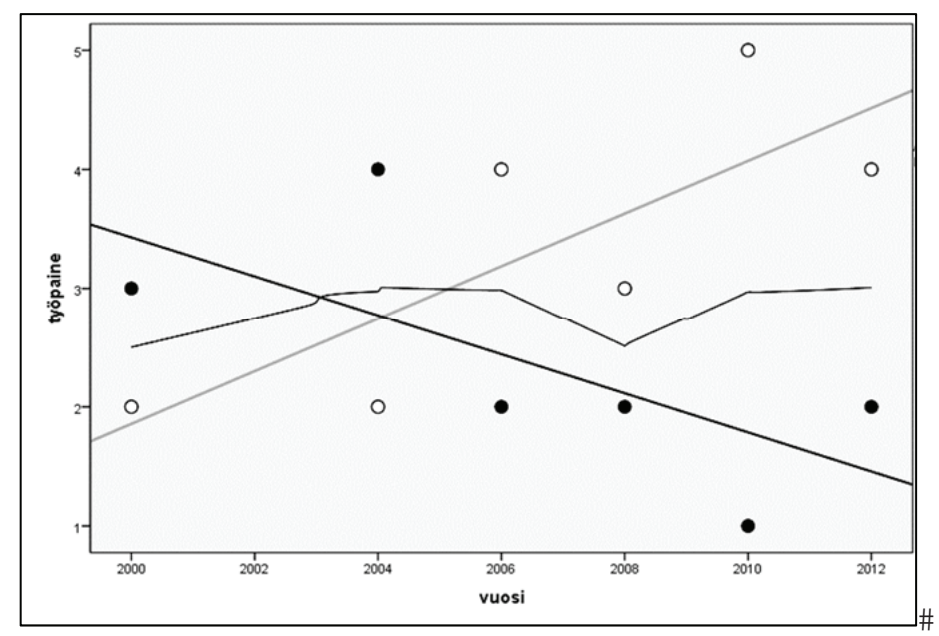

Kuvio 1. Latentin kasvukäyrämallin perusasetelmaa havainnollistava sirontakuvio. Kahden fiktiivisen tapauksen mittaustulokset (valkeat pallot ja mustat pallot) työpaineen mittarilla (asteikolla 1-5) kuutena mittauskertana (2000-2012), tapausten latentit lineaariset kasvukäyrät (harmaa nouseva ja musta laskeva suora) sekä mittaustulosten keskiarvot peräkkäisinä ajankohtina yhdistävä käyrä (murtoviiva).

sa on enemmän työnsä hallitsevia, eikä siitä, että kenenkään yksittäisen sosiaalityöntekijän työn hallinta olisi ajan myötä muuttunut. Muutoksen selvittäminen vaatii toistomittauksista muodostuvaa pitkittäisaineistoa.

Toinen poikkileikkausaineistoista saatavan muutoskuvan heikkous on se, että siinä mittaustulokset täytyy olettaa ajan suuntaan virheettömiksi. Työn kuormittavuuden mittaaminen useamman osion summalla lisää kyllä periaatteessa mittauksen "paikallista" reliabiliteettia, mutta ajankohtaan liittyvän satunnaisen mittausvirheen kontrollointi vaatii pitkittäisaineistoa ja latenttien muuttujien käyttöä. Parhaiten tehtävä onnistuu latentiksi kasvukäyrämalliksi (latent growth model, LGM) kutsutulla rakenneyhtälömallilla (Bollen \& Curran 2006; McArdle 2015).
Kuviossa 1 on latentin kasvumallin idean havainnollistamiseksi esitetty kahden kuvitellun vastaajan mittaustulosten sirontakuvio ajan suhteen. Tapaus A on arvioinut työpaineensa (valkoiset pallot asteikolla 1-5) eri mittauskerroilla seuraavasti: 2, -, 2, 4, 3, 5, 4. Tapaus $\mathrm{B}: \mathrm{n}$ mittaustulokset (mustat pallot) ovat 3, -, 4, 2, 2, 1, 2. Latentissa kasvumallissa ajatellaan, että havaittujen mittaustulosten takana on jokaisen yksilön henkilökohtainen latentti "lentorata". Se on joko lineaarinen tai epälineaarinen, nouseva tai laskeva kasvukäyrä, jota eri ajankohtien mittaustulokset enemmän tai vähemmän uskollisesti noudattavat. Mittaustulosten poikkeamat tuosta latentista lentoradasta ajatellaan satunnaisiksi mittausvirheiksi. Kuviossa A:n ja B:n kasvukäyrät on oletettu lineaarisiksi (harmaa ja musta suora) eli ne ovat regressiosuoria. Nähdään, ettei yksikään mittaustulos osu 
täsmälleen kummankaan tapauksen latentille lentoradalle ja että kummankin latentti "käyrä" kuvaa mittaustulosten vaihtelua suunnilleen yhtä hyvin. Suorien yhtälöt saadaan pienimmän neliösumman menetelmällä (A: työpaine $=$ $1,86+0,22 \cdot$ vuosi, B: työpaine $=3,43$ - 0,16-vuosi). Tarkkaan ottaen A:n mittaustulokset ovat hieman lähempänä hänen nousevaa "kasvukäyräänsä" kuin B:n tulokset tämän laskevaa lentorataa (mallien $\mathrm{R}^{2}=0,62$ ja 0,47 ). B:n mittaustuloksissa on siis hieman enemmän ajan suuntaista satunnaista mittausvirhettä. Jos mittaustuloksia tarkasteltaisiin poikkileikkauksina, saataisiin selville vain mittauskertojen keskiarvot (murtoviiva) ja vaihtelu niiden ympärillä. Kuvion 1 aineistossa keskiarvot eivät näyttäisi "kehittyneen" suuntaan eikä toiseen, mutta mittaustulosten varianssi näyttäisi lisääntyneen.
Kasvukäyrämalliin päästään kuvion 1 tilanteesta siten, että tehdään A:n ja B:n (ja kaikkien toistomittausaineiston tapausten) latenttien kasvukäyrien yhtälön parametreista vakioiden sijaan muuttujat. Toisin sanoen annetaan kasvun lähtötasoa kuvaavan leikkauspisteen (intercept) ja kasvun suuntaa (plus tai miinus) ja jyrkkyyttä kuvaavan kulmakertoimen (slope) vaihdella tapausten välillä. Näille kahdelle (käyräviivaisen mallin tapauksessa kolmelle, neljälle jne.) kasvuparametrille voidaan sitten estimoida keskiarvot ja varianssit. Jälkimmäisiä voidaan selittää joillakin muilla muuttujilla, kuten iällä, sukupuolella ja ammattiryhmällä. Rakenneyhtälömallina toteutettu lineaarinen kasvumalli voidaan esittää kuvion 2 polkukaavion avulla.

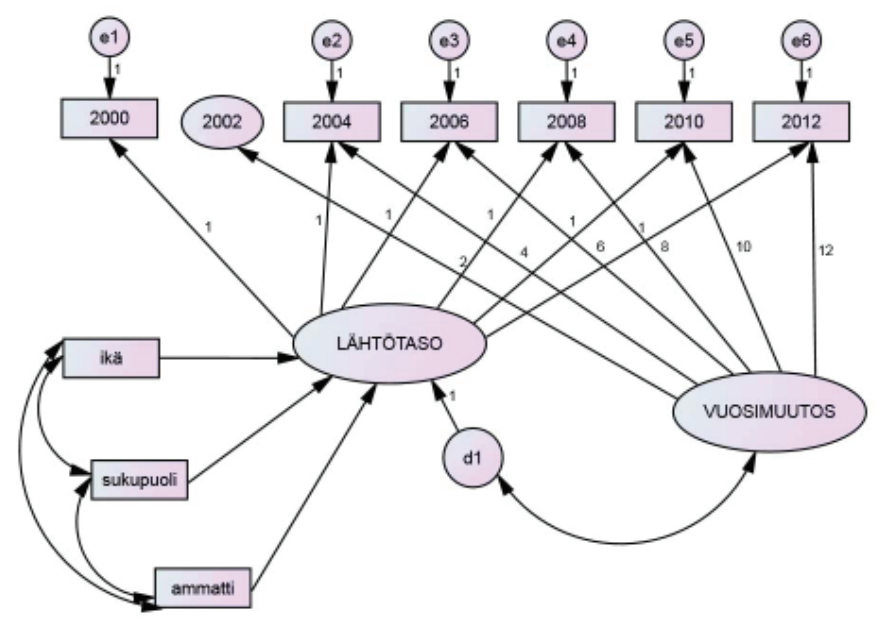

Kuvio 2. Rakenneyhtälömallina esitetty lineaarinen kasvukäyrämalli, jossa yksilöllisten regressiosuorien leikkauspisteiden (lähtötaso) vaihtelua selitetään iällä, sukupuolella ja ammattiryhmällä. 
Kuvion 2 kasvumalli on ytimeltään faktorimalli, jossa lähtötasoksi ja vuosimuutokseksi nimettyjen faktoreiden indikaattoreiden (vastaajan mittaustulokset eri ajankohtina) lataukset on kaikki kiinnitetty vakioiksi. Mallissa estimoidaan vain faktoreiden keskiarvot ja varianssit sekä indikaattoreiden uniikkivarianssit, jotka ajatellaan mittausvirheiksi. Jokaisen mittauskerran tulos ajatellaan siis kolmen latentin muuttujan eli lähtötason, vuosimuutoksen ja mittausvirheen summaksi. Esimerkiksi $2006=1$-lähtötaso + 6. vuosimuutos $+1 \cdot \mathrm{e} 3$. Vuoden 2002 mittaustulokset puuttuvat kaikilta tapauksilta, joten niiden paikalla on latentti "haamumuuttuja", jolla ei ole lainkaan mittausvirhettä. Tämä tarkoittaa, että sen arvot määräytyvät jäännöksettä kunkin tapauksen lähtötason ja vuosimuutoksen avulla. Mikäli aineistossa joiltakin tapauksilta puuttuu joidenkin muidenkin ajankohtien mittaustuloksia (kuten aineiston kaksi tapauksessa), voidaan kasvukäyrämalli silti testata, koska estimointimenetelmä korvaa automaattisesti puuttuvat havainnot vastaavanlaisilla henkilökohtaisilla haamumuuttujilla. Kaavion alaosa kertoo, että latentin lähtötasomuuttujan vaihtelua selitetään vastaajien iän, sukupuolen ja ammattiryhmän vaihtelulla.

Sekä poikkileikkausaineistojen regressiomallit että kuvion 2 rakenneyhtälömalli estimoitiin Mplus 7.2 -ohjelmistolla (Muthén \& Muthén 1998-2012). Estimointimenetelmänä käytettiin "robustia" suurimman uskottavuuden menetelmää (MLR), joka korjaa muuttujien mahdollisesta epänormaalisuudesta johtuvan harhan estimaattien keskivirheissä. Jos muuttujat ovat normaalisti jakaantuneita, tulokset ovat samat kuin tavallisen ML:n. Jos ne ovat vinoja tai huipukkaita, MLR tuottaa luotettavammat testitulokset. Itse regressiokertoimet ovat kummallakin menetelmällä samat.

Regressiomallit estimoitiin ilman askellusta, koska tarkoitus oli ainoastaan saada ikä- ja sukupuolivakioidut estimaatit ammattiryhmien kuormittavuusmittareiden tasolle. Kasvukäyrämalli rakennettiin vaiheittain testaamalla ensin malli, jossa vuosimuutos kiinnitettiin nollaksi. Sen jälkeen testattiin malli, jossa se on lineaarinen, ja lopuksi malli, jossa muutos on epälineaarinen (malliin lisättiin toisen asteen kasvutekijä). Mallin osuvuus parani ensimmäisestä toiseen, mutta kolmannen mallin tuoma osumalukujen parannus oli minimaalinen täydellisessä toistomittausaineistossa (ja epätäydellisessä se ei tietenkään ollut identifioituva), joten kuvion 2 mukainen lineaarinen kasvumalli katsottiin parhaaksi osuvuuden ja yksinkertaisuuden yhdistelmäksi.

\section{TulokseT}

\section{Ammattiryhmien erot työn kuormittavuu-} dessa

Taulukossa 2 on esitetty poikkileikkausaineistoilla estimoitujen regressiomallien standardoimattomat kertoimet ja selitysasteet. Jälkimmäiset ovat melko vaatimattomia ja osoittavat, että ammattiryhmän, sukupuolen ja iän avulla pystytään selittämään $1,0-8,9$ prosenttia työn kuormittavuuden vaihtelusta: eniten vaihtelusta työn hallinnassa, vähiten työpaineissa. Iällä oli muutamassa mittauspisteessä epälineaarinen vaikutus. Koska toisen asteen termin etu- 
merkki oli lisäksi negatiivinen, se tarkoittaa, että keski-ikäisillä työn hallinta, palkitsevuus ja työpaineet olivat nuoria ja vanhoja korkeammalla tasolla (kun ammattiryhmä ja sukupuoli on vakioitu). Sukupuolella ei ollut tilastollisesti nollasta poikkeavia kertoimia yhtä poikkeusta lukuun ottamatta, mutta työpaineiden selitysmallissa muuttujan kerroin käyttäytyi hyvin johdonmukai- sesti. Kaikissa mittauspisteissä naisten työpaineet olivat miehiä korkeammalla.

Sosiaalityöntekijöiden ja muiden ikäja sukupuolivakioitujen keskiarvojen vertailu eri ajankohtina on esitetty kuviossa 3. Tärkein havainto on yksinkertainen. Sosiaalityöntekijät ovat joka poikkileikkauksessa muiden alapuolella työn hallinnassa ja sen palkitsevuudes-

Taulukko 2. Työn kuormittavuuden kolmen ulottuvuuden vaihtelua selittävät regressiomallit kunkin mittauskerran poikkileikkausaineistoissa. Standardoimattomat regressiokertoimet, tilastolliset merkitsevyydet $(\star<0,05, \star \star<0,01, \star \star \star<$ $0,001)$.

\begin{tabular}{|c|c|c|c|c|c|c|}
\hline Vuosi & 2000 & 2004 & 2006 & 2008 & 2010 & 2012 \\
\hline \multicolumn{7}{|l|}{ Työn hallinta (1-5) } \\
\hline Leikkauspiste (MUUT) & 4,00 & 4,19 & 3,91 & 3,90 & 4,00 & 4,10 \\
\hline SOSIAALITYÖNTEKIJÄ & $-0,11 \star$ & $-0,11$ & $-0,04$ & 0,03 & $-0,06$ & $-0,09 \star$ \\
\hline Ikä & $-0,00$ & 0,00 & 0,00 & $-0,00$ & $0,01 \star$ & $-0,00$ \\
\hline Ikä^ikä & 0,00 & $-0,00 \star$ & $-0,00 \star \star$ & 0,00 & 0,00 & 0,00 \\
\hline sukupuoli & 0,04 & $-0,07$ & $0,21 \star$ & 0,00 & 0,05 & $-0,10$ \\
\hline $100 \mathrm{R}^{2}$ & 1,0 & 3,6 & 4,5 & 0,4 & 2,7 & 1,4 \\
\hline \multicolumn{7}{|l|}{ Työn palkitsevuus (1-4) } \\
\hline Leikkauspiste (MUUT) & 2,79 & 3,06 & 2,84 & 2,91 & 3,18 & 3,11 \\
\hline SOSIAALITYÖNTEKIJÄ & $-0,28 \star \star$ & $-0,32^{\star \star \star}$ & $-0,09$ & $-0,06$ & $-0,17 \star$ & $-0,13^{\star}$ \\
\hline Ikä & 0,00 & $0,02 \star \star \star$ & 0,01 & 0,01 & 0,01 & 0,00 \\
\hline Ikä^ikä & 0,00 & $-0,00^{\star}$ & $-0,00$ & $0,00 \star$ & 0,00 & 0,00 \\
\hline sukupuoli & 0,11 & 0,04 & 0,15 & $-0,02$ & $-0,12$ & $-0,03$ \\
\hline $100 \mathrm{R}^{2}$ & 3,2 & 8,9 & 2,4 & 1,3 & 3,2 & 1,2 \\
\hline \multicolumn{7}{|l|}{ Työpaineet (1-5) } \\
\hline Leikkauspiste (MUUT) & 3,34 & 3,24 & 3,35 & 3,24 & 3,30 & 3,40 \\
\hline SOSIAALITYÖNTEKIJÄ & $0,22 \star \star$ & $0,26 \star$ & 0,19 & 0,09 & $0,27 \star$ & $0,24 \star \star \star$ \\
\hline Ikä & $0,01 \star$ & $-0,01$ & $-0,00$ & $-0,01 \star \star$ & $-0,01$ & $-0,00$ \\
\hline Ikä^ikä & $-0,00 \star \star$ & 0,00 & 0,00 & $-0,00$ & 0,00 & 0,00 \\
\hline sukupuoli & 0,13 & 0,18 & 0,11 & 0,23 & 0,16 & 0,00 \\
\hline $100 \mathrm{R}^{2}$ & 3,1 & 3,5 & 1,2 & 2,5 & 2,5 & 1,7 \\
\hline $\mathrm{N}$ & 624 & 286 & 304 & 392 & 381 & 1023 \\
\hline
\end{tabular}


sa ja yläpuolella työpaineissa. Erot ovat pienimmät työn hallinnassa ja suurimmat työpaineissa. Ajallisesti työn hallinta ja työpaineet näyttävät pysyneen kummallakin ryhmällä suunnilleen samalla tasolla, mutta työn palkitsevuus näyttää nousseen melko selvästi. Koska kyse on kuitenkin poikkileikkauksista, muutosta koskeva päätelmä voi olla virheellinen.

\section{Työn kuormittavuuden muutos}

Poikkileikkausaineistoissa näkyvät muutokset mittareiden keskiarvoissa eivät siis kerro työn kuormittavuuden vaan ryhmien koostumuksen muutoksesta. Puhtaassa toistomittausaineistossa erot syntyvät taas yksinomaan siitä, että yksilöiden vastaukset esitettyihin kysymyksiin ovat ajan myötä muuttu-
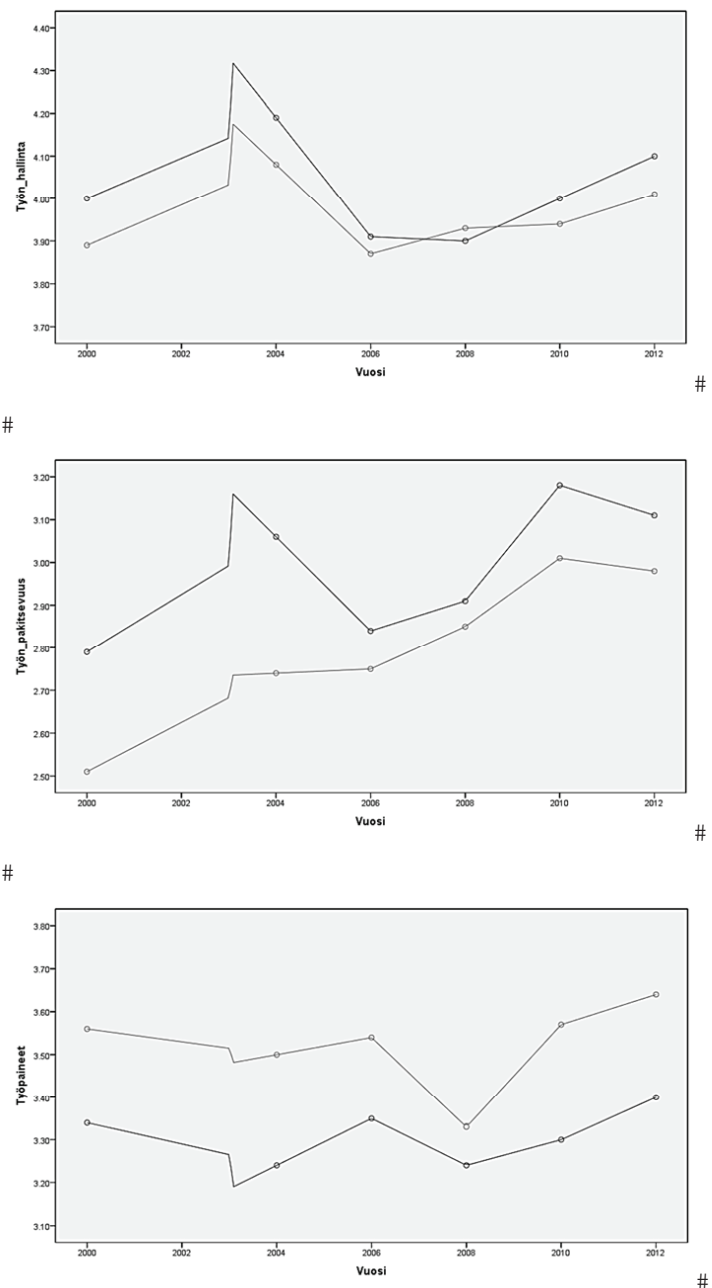

Kuvio 3. Työn\#hallinnan (1-5), palkitsevuuden (1-4) sekä työpaineiden (1-5) ikä- ja sukupuolivakioidut keskiarvot kussakin poikkileikkausaineistossa sosiaalityöntekijöillä (1) vaaleanharmaa ja muilla (2) tummanharmaa. 
neet. Seka-aineistossa, jossa vastaajilla on mittaustulos vähintään kahdesta ajankohdasta, on piirteitä kummastakin. Kahden jälkimmäisen aineiston avulla voidaan vastata kysymykseen, ovatko mittausajankohtien välillä havaittavat erot merkki järjestelmällisestä muutoksesta työn kuormittavuuden kasvusta tai sen vähenemisestä vai ovatko ne tulkittavissa satunnaisesta vaihtelusta (mittausvirheestä) johtuviksi.

Taulukon 3 kasvumallit vastaavat sisällöllisesti edellä esitettyjä regressioanalyyseja. Selittäjät ovat samoja, mutta nyt selitettävänä on yksilöllisten lineaaristen "lentoratojen" lähtötason vaihtelu. Jäännöstermien riippumattomuusoletusta testaavat mallien osumaluvut osoittavat kaikki riittävän hyviä arvoja (erityisesti RMSEA < 0,05, CFI ja TLI $>0,95)$, joten mallia voi pitää empiirisesti mahdollisena.

Lähtötaso tarkoittaa muiden kuin sosiaalityöntekijöiden ryhmän keskiikäisten miesten regressiosuorien leikkauspisteen keskiarvoa vuonna 2000. Naisilla työn hallinnan lähtötason keskiarvo on hieman miehiä korkeammal-

Taulukko 3. Työn kuormittavuuden kolmen ulottuvuuden muutosta kuvaavat latentit kasvukäyrämallit pitkittäisaineistosta (aineisto $2+$ aineisto 3) estimoituna. Leikkauspisteet ("lähtötaso", "vuosimuutos") ja standardoimattomat regressiokertoimet, tilastolliset merkitsevyydet $(\star<0,05, \star \star<0,01, \star \star \star<0,001)$.

\begin{tabular}{|c|c|c|c|}
\hline & $\begin{array}{c}\text { Työn hallinta } \\
(1-5)\end{array}$ & $\begin{array}{c}\text { Työn palkitsevuus } \\
(1-4)\end{array}$ & $\begin{array}{l}\text { Työpaineet } \\
\quad(1-5)\end{array}$ \\
\hline LÄHTÖTASO (muut) & 4,05 & 2,97 & 3,20 \\
\hline Sosiaalityöntekijä & $-0,12^{\star \star \star}$ & $-0,22^{\star \star \star}$ & $0,21^{\star \star \star}$ \\
\hline ikä & $0,00^{\star}$ & $0,00 \star \star \star$ & 0,00 \\
\hline ikäÆikä & 0,00 & 0,00 & 0,00 \\
\hline sukupuoli & $0,04^{\star}$ & $-0,02$ & $0,16 \star \star \star$ \\
\hline $\begin{array}{l}\text { VUOSIMUUTOS } \\
\text { (kaikki) }\end{array}$ & $-0,006^{\star \star \star}$ & $0,007 \star \star \star$ & $0,022 \star \star \star$ \\
\hline 100R ² (lähtötaso) & 1,9 & 3,0 & 2,3 \\
\hline$\chi^{2}$ & 137,96 & 134,43 & 175,92 \\
\hline DF & 36 & 36 & 36 \\
\hline $\mathrm{P}$ & 0,000 & 0,000 & 0,000 \\
\hline RMSEA & 0,025 & 0,024 & 0,029 \\
\hline CFI & 0,979 & 0,980 & 0,970 \\
\hline TLI & 0,978 & 0,978 & 0,968 \\
\hline SRMR & 0,049 & 0,023 & 0,037 \\
\hline $\mathrm{N}$ & 4604 & 4604 & 4604 \\
\hline
\end{tabular}


la. Työn palkitsevuudessa ei sukupuolieroa ole, mutta työpaineissa ero on suuri: naisilla paineet ovat keskimäärin 0,16 yksikköä korkeammalla kuin miehillä. Iällä on lineaarinen efekti työn hallinnan ja sen palkitsevuuden tasoon: työvuosien myötä hallinta ja palkitsevuus lisääntyvät. Sen sijaan työpaineet eivät näytä katsovan ikää. Kahden ammattiryhmän erot ovat samankaltaiset kuin poikkileikkausaineistoissa: sosiaalityöntekijät kokevat hallitsevansa työnsä muita huonommin, työ palkitsee heitä selvästi muita vähemmän, ja työpaineet ovat sosiaalityöntekijöillä muita selvästi korkeammalla tasolla.

Tämän sosiaalityöntekijäefektin suuruutta voi arvioida vertaamalla sitä sukupuoliefektiin: työpaineiden osalta ero on samaa luokkaa. Työn hallinnan ja palkitsevuuden osalta sukupuoliero kalpenee sosiaalityöntekijöiden ja muiden eron rinnalla. Efektikoon mittana käytetään usein Cohenin D:ksi kutsuttua suuretta (keskiarvoero/keskihajonta), jonka arvoa $>0,2$ pidetään pienenä, $>0,5$ keskisuurena tai $>0,8$ suurena. Tässä sen arvoksi saadaan 0,35 . Efekti on siis pientä suurempi.

Mallin vuosimuutostermi on kaikkien vastaajien henkilökohtaisten regressiokertoimien keskiarvo, joka kertoo, mihin suuntaan ja kuinka jyrkästi kukin mittari on lineaarisesti ajan myötä muuttunut. Nähdään, että työn hallinta on lievästi laskenut, työn palkitsevuus saman verran noussut ja työpaineet kasvaneet niihin nähden kolminkertaisesti.

Nämä muutostrendit ovat siis todellisia, mutta keskimäärisiä, sillä taulukon 3 malleissa ei vuosimuutosta kuvaavalla latentilla muuttujalla ole selittäjiä. Niinpä lopuksi taulukon 3 mallit estimoitiin erikseen sosiaalityöntekijöille ja muille, jolloin edelleen vuosimuutos tarkoitti yksilöllisten regressiosuorien keskiarvoa, mutta nyt se saattoi olla ryhmissä erisuuruinen ja jopa erimerkkinen. Tulos on esitetty kuviossa 4 (mallien muita lukuja ei tässä esitettä).

Näemme, että työn hallinnan lasku ja työn palkitsevuuden nousu ovat suunnilleen samansuuntaisia kummassakin ryhmässä. Sen sijaan työpaineiden kehityksessä on selvä ero. Sosiaalityöntekijöiden paineet ovat pysyneet ennallaan tai jopa hieman laskeneet, mutta muiden paineet (lastentarhanopettajat, erityisopettajat ja psykologit) ovat nousseet, niin että mallin mukaan he ovat ohittaneet sosiaalityöntekijät vuoden 2009 paikkeilla. 


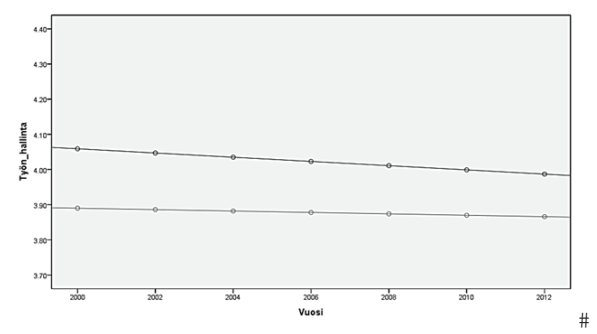

\#

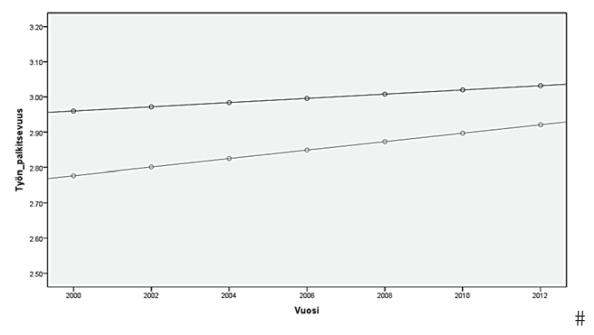

$\#$

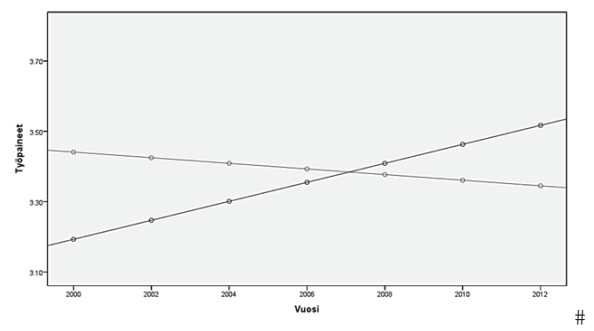

Kuvio 4. Sosiaalityöntekijöiden (1) vaaleanharmaa ja muiden (2) tummanharmaa pitkittäisaineistosta estimoitu lineaarinen kasvukäyrä.

\section{JоHTOPÄÄTÖKSET}

Artikkelin pohjana olevassa tutkimuksessa tarkasteltiin sosiaalityöntekijöiden työn kuormittavuutta verrattuna vertailuryhmään (blokkiin) jonka muodostivat eräät muut ammattiryhmät, joiden työ on osin koulutuksen ja alan naisvaltaisuuden osalta verrattavissa sosiaalityöhön. Näissä ammateissa tehdään ihmisläheistä vuorovaikutustyötä. Ammatit, joihin sosiaalityöntekijöitä verrattiin, olivat lastentarhanopetta- jat, erityisopettajat ja psykologit. Tutkimuksessa vastattiin kysymyksiin (1) millainen on sosiaalityöntekijöiden työn kuormittavuus verrattuna näihin muihin ryhmiin ja (2) miten työn kuormittavuus on muuttunut vuosina 2000-2012.

Tässä artikkelissa kuormittavuutta tarkasteltiin työn hallinnan, työn palkitsevuuden ja työn paineiden kautta. Työhön liittyvissä psykososiaalisissa tekijöissä (työpaineet, työn hallinta ja 
työn palkitsevuus) ei havaittu muutosta vuosina 2000-2012 missään tutkituista ammattiryhmistä. Havaittiin kuitenkin, että sosiaalityöntekijät kokivat työssään keskimäärin enemmän kuormitusta kuin psykologit, erityisopettajat tai lastentarhanopettajat.Ikä ja sukupuoli eivät selittäneet eroja. Sosiaalityön luonteesta lastentarhanopettajien, erityisopettajien ja psykologien työhön ei ole sellaista tietoa, joka auttaisi selittämään sosiaalityön kokemista kuormittavammaksi kuin muut ammatit. Kuitenkin näyttää siltä, että lastentarhanopettajien, erityisopettajien ja psykologien työpaineiden kasvu on ollut suhteessa suurempaa kuin sosiaalityöntekijöiden. Tieto on hankalasti tulkittava. Tosiasiassa sosiaalityöntekijöiden työ on selkeästi tutkimuksen perusteella kuormittavampaa, mutta muiden ryhmien kuormittavuus on kasvanut suhteessa enemmän. Työn hallinnan ja palkitsevuuden sekä työpaineiden trendi oli tasaisen nouseva kaikissa ryhmissä. Näistä kahden ensimmäisen odottaisikin työuran myötä kasvavan, mutta työpaineiden tulos yllättää. Niiden odottaisi pikemminkin kokemuksen karttuessa hellittävän, jos työpaineet riippuvat työntekijästä itsestään. Selitystä voi hakea ulkoisista tekijöistä kuten työelämän muutoksista paineisempaan suuntaan.

Suomessa on tapahtunut melko suuria muutoksia ammattirakenteessa. Kun puhutaan nykyisestä työelämästä ja työntekijöistä, on kyse aika erilaisesta joukosta kuin muutama vuosikymmen sitten (Sutela \& Lehto 2014). Saarinen $\mathrm{ym}$. totesivat omassa tutkimuksessaan, että sosiaalityöntekijät ovat hyvin kuormittuneita (Saarinen ym. 2012). Samat asiat toistuvat tutkimuksissa, joissa on kartoitettu sosiaalityöntekijöiden työ- hyvinvointia ja selitetty työn kuormittavuutta sosiaalityön luonteesta käsin (Saarinen ym. 2012; Tham 2007; Mänttäri-van der Kuip 2015a; Hämäläinen \& Niemelä 2006; Rantonen ym. 2017; Baldschun ym. 2016). Suomalaisissa tutkimuksissa on todettu, että sosiaalityöntekijöillä on kaksikertainen riski joutua mielenterveydenhäiriöiden takia työkyvyttömäksi verrattuna muihin ihmistyön ammatteihin kuntaalalla (Viinamäki 1997; Rantonen ym. 2017). Tämän ja aiempien tutkimusten perusteella pääselitys kokemukselle sosiaalityön kuormittavuudesta löytynee sosiaalityön luonteesta suhteessa muihin ammatteihin. Määräaikaisten sosiaalityöntekijöiden osuus oli suurinta sosiaalityön ja vertailublokin välillä vertailtuna. Tätä selittää todennäköisesti sijaisten suuri osuus sosiaalityöntekijöinä kelpoisten sosiaalityöntekijöiden puuttuessa.

Toteuttamamme kaltaista pitkittäistutkimusta on tehty vähän verrattuna poikkileikkaustutkimuksiin joita löytyy jonkin verran (mm. Viinamäki 1997; Saarinen ym. 2012; Niemelä \& Hämäläinen 2001; Hämäläinen \& Niemelä 2006; Mänttäri-van der Kuip 2015b). Alentuneet valmiudet harjoittaa eettisesti vastuullista sosiaalityötä ovat yhteydessä työperäinen hyvinvoinnin heikkenemiseen, mutta kuitenkin sosiaalityöntekijät kokevat myös sitoutumista työssään ja he kertovat innostuksesta ja nautinnosta työssään (Mänttäri-van der Kuip 2015a, 3). Koko kunta-ala on ollut muutosten keskellä 2000-luvulla. Edelleen kunnissa tehdään rakenteellisia muutoksia, jotka vaikuttavat myös kuntien työntekijöiden arkeen. Lisäksi taloudellisen tilanteen vaikutukset näkyvät säästöpai- 
neiden kanssa kamppailevissa kunnissa. Muutokset voivat vaikuttaa työntekijöiden hyvinvointiin ja haluun jatkaa työtään kunnan palveluksessa. (Salo ym. 2012, 19; McFadden 2015.) Sosiaalityön kehittäminen tulisi kohdistaa asiakkaiden tarpeisiin sekä itse työn ja palveluiden sisältöön eli siihen, miten työtä voisi tehdä hyvin ja eettisesti niin, että asiakkaat tulevat paremmin autetuiksi ja että heidän toimintamahdollisuutensa paranevat (Mänttäri-van der Kuip 2016, 9). Sosiaalityön opetus antaa valmiuksia työskennellä eettisesti ja ammattia edelleen kehittävänä toimijana (Moran \& Hughes 2006, 501). Kehityskulku työn kuormitustekijöiden osalta on mielenkiintoinen, sillä kentältä kuulee usein sosiaalityön muuttuneen entistä haastavammaksi, työtahdin kiireisemmäksi, asiakkaiden määrän suuremmaksi ja resurssien kaiken kaikkiaan vähentyneen (Salo ym. 2016, 23; Ravalier 2017).

Kuitenkaan tämän artikkelin pohjana oleva tutkimus ei tue väitettä vaan kokemus kuormittuneisuudesta on verraten sama sosiaalityöntekijöillä vuonna 2000 ja 2012. Havaittujen kokemusten taustalla saattaa olla useita eri selityksiä. Vaikka työ oli reilussa vuosikymmenessä muuttunut, niin kokemus kuormittavuudesta ei ollut kuitenkaan muuttunut. Sosiaalityöntekijöiden kuormittavuus on selkeästi korkeampaa kuin vertailuryhmässä (lastentarhanopettajat, erityisopettajat ja psykologit). Vaikuttaa siltä, että työn luonne vertailuryhmässä on pysynyt samankaltaisena. Työntekijöiden kuormittuneisuuteen tulee pyrkiä vaikuttamaan riittävän varhaisessa vaiheessa. Työterveyslaitoksen tutkimukset ovat osoittaneet, että työyhteisöjen ja johdon kannattaa sat- sata voimavarojen lisäämiseen työssä. Erilaisia motivoinnin ja sitouttamisen keinoja tulisi kehittää, jotta työyhteisöllä olisi mahdollisuus onnistua luomaan positiivinen työyhteisö, jossa jokainen yksilö voi kokea turvallisuutta ja kehittyä ammatillisesti. (Oksanen 2012, 125.) Sosiaalityön sisältö vaihtelee paljon eri sosiaalityön aloilla. Yhteneväistä kuvaa on tästä syystä vaikeaa saada. Työntekijälle on tärkeää tulla kuulluksi ja nähdyksi niin, että hänen kykynsä, osaamisensa ja voimavaransa nähdään ja että hän voi käyttää kykyjään työssään. Sosiaalityön haasteeksi voi muodostua yksilön itsemääräämisoikeuteen puuttuminen, joka osaltaan voi lisätä kuormittuneisuutta työssä. Tulevaisuudessa olisi tärkeää tutkia sitä, mistä kokemus kuormittavuudesta muodostuu ja miten yhteiskunnalliset muutokset vaikuttavat työn tekemiseen ja työhyvinvointiin.

\section{KirjallisuUs}

Adams, Richard \& Boscarino, Joseph \& Figley, Charles (2006) Compassion fatigue and psychological distress among social workers: A Valditation Study. American Journal of orthopsychiatry, 76 (1), 103-108. https://doi.org/10.1037/00029432.76.1.103

Arnkil, Eirik (toim.) (1991) Sosiaalityön rationalisointi. Paradoksaalinen tehtävä. Kaksi sosiaalityön tutkiva kehittäminen projektia. Raportteja 9. Helsinki: Sosiaalija terveyshallitus.

Baldschun, Andreas \& Töttö, Pertti \&Hämäläinen, Juha \& Salo, Paula (2016) Modeling the Occupational Well-Being of Finnish Social Work Employees: A Multigroup Confirmatory Factor Analysis. Human Service Organizations: Management, Leadership \& Governance 40 (5), 524-539. https://doi.org/10.1080/2 3303131.2016.1178201 
Balloch, Susan \& Pahl, Jan \& McLean, John (1998) Working in the social services. Job satisfaction, stress and violence. British Journal of Social Work 28 (1), 329-350. https://doi.org/10.1093/oxfordjournals. bjsw.a011343

Bollen, Kenneth \& Curran, Patrick (2006) Latent Curve Models. A Structural Equation Perspective. Hobocen, New Jersey: Wiley. https://doi.org/10.1353/ sof. 0.0084

Coffrey, Margaret \& Dugdill, Lindsey \& Tattersall, Andy (2004) Stress in social services: Mental wellbeing, constraints and job satisfaction. British Journal of Social Work 34 (5), 735-746. https://doi. org/10.1093/bjsw/bch088

Huxley, Peter \& Evans, Sherill \& Gately, Claire \& Webber, Martin \& Mears, Alex \& Pajak, Sarah \& Kendall, Tim \& Medina, Jibby \& Katona, Cornelius (2005) Stress and pressures in mental health social work. The workers speaks. British Journal of Social Work 35 (7), 1063-1079. https://doi. org/10.1093/bjsw/bch218

Hämäläinen, Juha \& Niemelä, Pauli (2006) Jaksamisen edistäminen vaativissa sosiaalialan tehtävissä työyhteisöjä kehittämällä. Kuopion yliopiston selvityksiä E. Yhteiskuntatieteet 37. Kuopio: Kuopion yliopiston kirjasto.

Hämäläinen, Juha (2014) Tiedontuotanto sosiaalityön rakenteellisena kysymyksenä. Teoksessa Anneli Pohjola \& Merja Laitinen \& Marjaana Seppänen (toim.) Rakenteellinen sosiaalityö. Sosiaalityön tutkimuksen vuosikirja 2014. Kuopio: UNIpress, 64-8.

Hämäläinen, Juha \& Shardlow, Steven (2016) Vertaileva sosiaalityön tutkimus kansainvälisen sosiaalityön perustekijänä. Teoksessa Maija Jäppinen, Anna Metteri, Satu Ranta-Tyrkkö \& Pirkko-Liisa Rauhala (toim.) Kansainvälinen sosiaalityö. Käsitteitä, käytäntöjä ja kehityskulkuja. Sosiaalityön tutkimuksen vuosikirja. Tallinna: United Press Global, 40-54. https://doi. org/10.30668/janus.79721

Karjalainen, Pekka \& Sarvimäki, Pirjo (toim.) (2005) Sosiaalityö hyvinvointipolitiikan välineenä 2015 - toimenpideohjelma. Helsinki:Yliopistopaino.

Kankainen, Leila (2012) Aikuissosiaalityön haasteet. Institutionaalinen näkökulma kehittämishankkeiden kuvaamaan sosiaalityöhön. Lisensiaatintyö. Tampere: Tampereen yliopisto.

Karasek, Robert \& Theorell, Tores (1990) Healthy Work. Stress, Productivity, and The Reconstruction Of Working Life. New York, NY: Basic Books. https://doi. org/10.1002/npr.4040090411

Ketokivi, Mikko (2015) Tilastollinen päättely ja tieteellinen argumentointi. Gaudeamus: Helsinki.

Laine, Marjukka \& Kokkinen, Lauri \& Kaarlela-Tuomaala, Anu \& Valtanen, Elisa \& Elovainio, Marko \& Keinänen, Mika \& Suomi, Reima (2010) Sosiaali- ja terveysalan työolot. Helsinki: Työterveyslaitos.

Lindqvist, Tuija \& Rajavaara, Marketta (toim.) (1994) Kehittämistyö itseanalyysiin. Raportteja 147. Helsinki: Stakes.

Lloyd, Chris \& Mckenna, Kryss \& King, Robert (2005) Sources of stress experienced by occupational therapists and social workers in mental health settings. Occupational Therapy International 12 (2), 81-94. https://doi.org/10.1002/oti.17

McArdle, John (2015) Latent Curve Modeling of Longitudinal Growth Data. Teoksessa Rick Hoyle (toim.) Handbook of Structural Equation Modeling. New York and London: The Guilford Press, 547 570 .

McFadden, Paula (2015) Measuring burnout among UK social workers A Community Care study. Community care. The heart of your social care career. UK: Reed Business Information: Community Care. https://doi.org/10.1046/j.13652524.2002.03833.x

Moran, Carmen C. \& Hughes, Lesley P. (2006) Coping with stress. Social work students and humor. Social Work Education, 25 (5), 501-517. https://doi. org/10.1080/02615470600738890

Meltti, Tero \& Kara, Hanna (2009) Sosiaalityöntekijöiden työolot, -ympäristö ja työhyvinvointi sekä niihin vaikuttavat tekijät. Teoksessa Laura Yliruka, Juha Koivisto \& Synnöve Karvinen-Niinikoski (toim.) Sosiaalialan työolojen hyvä kehittäminen. Sosiaali- ja terveysministeriön julkaisuja 2009:6. Helsinki: Sosiaali- ja terveysministeriö, 22-39. https://doi.org/10.26530/ oapen_622450

Muthén, L.K. and Muthén, B.O. (1998- 
2012). Mplus User's Guide. Seventh Edition. Los Angeles, CA: Muthén \& Muthén.

Mänttäri-van der Kuip, Maija (2016) Julkinen sosiaalityö pysyvän niukkuuden aikakaudella. Sirpa Kannasoja, Marjo Kuronen \& Tytti Poikolainen (toim.) Tutkiva sosiaalityö. Sosiaalityön aika. Sosiaalityön tutkimuksen seura. Talentia-lehti, 6-11.

Mänttäri-van der Kuip, Maija (2015a) Sosiaalityöntekijöiden työhyvinvointi ja toimintamahdollisuudet niukkuuden aikakaudella. Janus 23 (3), 329-335.

Mänttäri-van der Kuip, Maija (2015b) Work-Related Well-Being among Finnish Frontline Social Workers in an Age of Austerity. Jyväskylä Studies in Education, Psychology and Social Research 524. Jyväskylä: Jyväskylän yliopisto. https:// doi.org/10.1080/13691457.2014.913006

Niemelä, Pauli \& Hämäläinen, Juha (2001) Työuupumuksen ehkäisy ja lievittäminen sosiaalialan asiantuntijatehtävissä. Kolmen interventiomallin kokeilu ja arviointi. Kuopion yliopiston selvityksiä E. Yhteiskuntatieteet 25. Kuopio: Kuopion yliopisto, Sosiaalitieteiden laitos.

Niemelä, Pauli (2011) Sosiaalityö hyvinvointietiikan toteuttajana. Teoksessa Aini Pehkonen \& Marja Väänänen-Fomin (toim.) Sosiaalityön arvot ja etiikka. Jyväskylä: PS-kustannus, 13-46.

Oksanen, Tuula (toim.) (2012) Hyvinvointihavaintoja. Tutkimustietoa kunta-alalta. Helsinki:Työterveyslaitos.

Payne, Malcolm (2005) Modern Social Work Theory. Houndmills, Basingstoke: Palgrave Macmillan.

Rantonen, Otso \& Alexanderson, Karin \& Pentti, Jaana \& Kjeldgård, Linnea \& Hämäläinen, Juha \& Mittendorfer-Rutz, Ellenor \& Kivimäki, Mika \& Vahtera, Jussi \& Salo, Paula (2017) Trends in work disability with mental diagnoses among social workers in Finland and Sweden in 2005-2012. Epidemiology and Psychiatric Sciences 26 (6), 644-654. https://doi. org/10.1017/s2045796016000597

Rauhala, Pirkko-Liisa (1991) Sosiaalialan työn kehittäminen. Tutkimus sosiaalialan työn yhteiskunnallisista ehdoista ja työn sisällöstä, loppuraportti. Yhteiskuntatieteiden tutkimuslaitos. Tampere: Tampereen yliopisto.
Raunio, Kyösti (2003) Sosiaalityö murroksessa. Helsinki: Gaudeamus.

Ravalier M Jermaine (2017) UK Social Workers. Working Conditions and Wellbeing. UK: British Association of Social Workers.

Saarinen, Arttu \& Blomberg, Helena \& Kroll, Christian (2012) Liikaa vaadittu? Sosiaalityöntekijöiden kokemukset työnsä kuormittavuudesta ja ristiriitaisuudesta Pohjoismaissa. Yhteiskuntapolitiikka 77 (4), 403-418.

Salo, Paula \& Rantonen, Otso \& Aalto, Ville \& Oksanen, Tuula \& Vahtera, Jussi \& Junnonen, Sanna-Riitta \& Baldschun, Andreas \& Väisänen, Raija \& Mönkkönen, Kaarina \& Hämäläinen, Juha (2016) Sosiaalityöntekijöiden hyvinvointi. Sosiaalityön kuormittavuus, voimavaratekijät ja sosiaalityöntekijöiden mielenterveys. Helsinki:Työterveyslaitos.

Shardlow, Steven \& Hämäläinen, Juha (2015) Comparative Social Work. Teoksessa Edward J. Mullen (toim.) Oxford Bibliographies in Social Work. New York: Oxford University Press. https://doi. org/10.1093/obo/9780195389678-0193

Siegrist, Johannes \& Wege, Natalia \& Pühlhofer, Frank \& Wahrendorf, Morten (2009) A short generic measure of work stress in the era of globalization. Effortreward imbalance. Int Arch Occup Environ Health 82 (2),1005-1013. https:// doi.org/10.1007/s00420-008-0384-3

Sutela, Hanna \& Lehto, Anna-Maija (2014) Työolojen muutokset 1977-2013. Helsinki:Tilastokeskus.

Tanninen, Timo \& Julkunen, Ilse (1993) Elämää säästöliekillä. Tutkimus toimeentulotuen pitkäaikaisista asiakkaista Pohjoismaiden pääkaupungeissa. Stakes tutkimuksia 32. Helsinki: Stakes.

Tham, Pia (2007) Why are they leaving? Factors affecting intention to leave among social workers in child welfare. British Journal of Social Work 37 (7), 1225-1246. https://doi.org/10.1093/bjsw/bcl054

Työministeriö (2002) Työssä jaksamisen ohjelma. Opas työn kuormittavuuden arvioimiseen. Kuorma kevyemmäksi. Helsinki:Työministeriö.

Viinamäki, Tanja (1997) Opettajien ja sosiaalityöntekijöiden psyykkinen rasittuneisuus. Väitöskirja. Kuopio: Kuopion yliopisto. 